\title{
Methanol emissions from maize: Ontogenetic dependence to varying light conditions and guttation as an additional factor constraining the flux
}

\author{
A. Mozaffar ${ }^{\text {a, b }}$, N. Schoon ${ }^{\text {b }}$, A. Digrado ${ }^{c}$, A. Bachy ${ }^{\text {a }}$, P. Delaplace ${ }^{\text {c }}$, P. du Jardin ${ }^{\text {, }}$, \\ M.-L. Fauconnier ${ }^{\mathrm{d}}$, M. Aubinet ${ }^{\mathrm{a}}$, B. Heinesch ${ }^{\mathrm{a}}$, C. Amelynck ${ }^{\text {b, e, * }}$ \\ ${ }^{\text {a }}$ Ecosystems - Atmosphere Exchanges, Dept. of Biosystem Engineering, University of Liege, Gembloux Agro-Bio Tech, 8 Avenue de la Faculté, B-5030, \\ Gembloux, Belgium \\ ${ }^{\mathrm{b}}$ Royal Belgian Institute for Space Aeronomy, Ringlaan 3, B-1180, Brussels, Belgium \\ ' Unit of Plant Biology, University of Liege, Gembloux Agro-Bio Tech, 2 Passage des Déportés, B-5030, Gembloux, Belgium \\ d Agro-Bio Systems Chemistry, University of Liege, Gembloux Agro-Bio Tech, 2 Passage des Déportés, B-5030, Gembloux, Belgium \\ e Department of Analytical Chemistry, Ghent University, Krijgslaan 281-S12, BE-9000 Ghent, Belgium
}

\section{H I G H L I G H T S}

- Methanol emission from young leaves is complex and drivers are not well understood.

- Methanol production from mature maize leaves may be light dependent.

- Guttation is a potential source of nighttime emissions from young maize plants.

- Emission rates are considerably lower than those observed in previous maize studies.

\section{A R T I C L E I N F O}

\section{Article history:}

Received 11 March 2016

Received in revised form 20 December 2016

Accepted 22 December 2016

Available online 23 December 2016

\section{Keywords:}

Maize

Methanol

VOC

Guttation

Emission modelling

\begin{abstract}
A B S T R A C T
Because of its high abundance and long lifetime compared to other volatile organic compounds in the atmosphere, methanol $\left(\mathrm{CH}_{3} \mathrm{OH}\right)$ plays an important role in atmospheric chemistry. Even though agricultural crops are believed to be a large source of methanol, emission inventories from those crop ecosystems are still scarce and little information is available concerning the driving mechanisms for methanol production and emission at different developmental stages of the plants/leaves. This study focuses on methanol emissions from Zea mays L. (maize), which is vastly cultivated throughout the world. Flux measurements have been performed on young plants, almost fully grown leaves and fully grown leaves, enclosed in dynamic flow-through enclosures in a temperature and light-controlled environmental chamber. Strong differences in the response of methanol emissions to variations in PPFD (Photosynthetic Photon Flux Density) were noticed between the young plants, almost fully grown and fully grown leaves. Moreover, young maize plants showed strong emission peaks following light/ dark transitions, for which guttation can be put forward as a hypothetical pathway. Young plants' average daily methanol fluxes exceeded by a factor of 17 those of almost fully grown and fully grown leaves when expressed per leaf area. Absolute flux values were found to be smaller than those reported in the literature, but in fair agreement with recent ecosystem scale flux measurements above a maize field of the same variety as used in this study. The flux measurements in the current study were used to evaluate the dynamic biogenic volatile organic compound (BVOC) emission model of Niinemets and Reichstein. The modelled and measured fluxes from almost fully grown leaves were found to agree best when a temperature and light dependent methanol production function was applied. However, this production function turned out not to be suitable for modelling the observed emissions from the young plants, indicating that production must be influenced by (an) other parameter(s). This study clearly shows that methanol emission from maize is complex, especially for young plants. Additional studies at different
\end{abstract}

\footnotetext{
* Corresponding author. Ringlaan 3, B-1180 Brussels, Belgium.

E-mail address: crist.amelynck@aeronomie.be (C. Amelynck).
} 
developmental stages of other crop species will be required in order to develop accurate methanol emission algorithms for agricultural crops.

() 2017 Elsevier Ltd. All rights reserved.

\section{Introduction}

Among all atmospheric hydrocarbons, methanol $\left(\mathrm{CH}_{3} \mathrm{OH}\right)$ is the second most abundant volatile organic compound in the troposphere, with mixing ratios ranging up to several tens of parts per billion (Riemer et al., 1998; Singh et al., 2000; Schade and Goldstein, 2001; Jacob et al., 2005; Wohlfahrt et al., 2015). Since it is an important precursor of carbon monoxide, formaldehyde and tropospheric ozone, it plays an important role in the global tropospheric chemistry (Tie et al., 2003; Millet et al., 2006; Duncan et al., 2007; Choi et al., 2010; Hu et al., 2011). Field and laboratory measurements have been carried out to characterize methanol sources and sinks. By integrating this knowledge into global chemistry and transport models, global annual budgets have been constructed (Singh et al., 2000; Heikes et al., 2002; Galbally and Kirstine, 2002; Tie et al., 2003; von Kuhlmann et al., 2003; Jacob et al., 2005; Millet et al., 2008; Stavrakou et al., 2011). Terrestrial plants have been found to be a major source of atmospheric methanol, with an annual global emission ranging from 75 to $280 \mathrm{Tg}^{-1}$ and constituting $60-80 \%$ of the total source strength. Moreover, recent research has revealed bi-directional exchange of methanol between terrestrial ecosystems and the atmosphere. Deposition of methanol is likely to be favoured by the formation of wet layers from which it may be removed chemically or biologically (Wohlfahrt et al., 2015; Laffineur et al., 2012; Niinemets et al., 2014; Seco et al., 2007). In leaves, methanol is mainly produced by the demethylation of pectin (Fall and Benson, 1996). Consequently, changes in cell wall structure related to growth (MacDonald and Fall, 1993; Nemecek-Marshall et al., 1995; Galbally and Kirstine, 2002; Karl et al., 2003; Harley et al., 2007), leaf abscission, the ageing of leaf tissues (Harriman et al., 1991) and intercellular air space generation (Nemecek-Marshall et al., 1995) play an important role in methanol emission from leaves. Therefore, methanol fluxes are affected by the seasonality of the vegetation, i.e. by growth stages and phenological processes (Bracho-Nunez et al., 2011). Several studies already reported that methanol emission from young leaves of various plant species is several times higher than that from mature leaves (MacDonald and Fall, 1993; NemecekMarshall et al., 1995; Karl et al., 2003; Custer and Schade, 2007; Harley et al., 2007; Hüve et al., 2007; Bracho-Nunez et al., 2011; Hu et al., 2011; Wells et al., 2012). Furthermore, methanol emission was found to be correlated to stomatal conductance (MacDonald and Fall, 1993; Nemecek-Marshall et al., 1995; Niinemets and Reichstein, 2003a), temperature (Schade and Goldstein, 2001; Karl et al., 2003, 2004, 2005; Brunner et al., 2007; Custer and Schade, 2007; Hüve et al., 2007; Folkers et al., 2008) and light conditions (Harley et al., 2007; Hüve et al., 2007; Folkers et al., 2008).

Maize (Zea mays L.) was chosen for this study because of its vast cultivation worldwide (13.7\% of the global cropland area, (FAO, 2015)) and because it is a fast-growing crop species which is potentially characterized by large methanol emissions. As methanol emission is the result of Pectin Methyl Esterase (PME) activity (Fall and Benson, 1996), which is in turn dependent on both the rate of cell division and cell expansion (which in turn are under the control of the plant hormones cytokinins (Taiz and Zeiger, 2010)), its emission rate from young developing leaves of fast growing maize plants may be higher than from slower-growing plant species. The little data available in the literature on BVOC emissions from maize (MacDonald and Fall, 1993; Das et al., 2003; Graus et al., 2013) indeed indicate that it could be an important plant species for exchanging methanol with the environment. Those studies, however, only covered a very limited period of the growing season and were conducted in very similar weather conditions. Recently, a field study was conducted to measure methanol exchanges from maize under natural environmental conditions for a whole growing season (Bachy et al., 2016). These flux measurements were performed at ecosystem-scale using the eddy covariance technique, thereby encompassing both soil and plant exchanges. Consequently, knowledge about methanol exchanges by the maize plant itself and their underlying exchange mechanisms remains limited. The present study aims to fill this knowledge gap by 1) evaluating the impact of varying PPFD on methanol emissions at constant temperature conditions in the environmental chamber, 2) studying the effect of leaf age on the methanol emission pattern and magnitude and 3) by confronting our measurements with the dynamic BVOC emission model of Niinemets and Reichstein (Niinemets and Reichstein, 2003a, 2003b) using different methanol production functions.

\section{Materials and methods}

\subsection{Plants and environmental conditions}

Investigations were carried out on silage maize (Zea mays L., variety Prosil, Caussade Semences, France) at three different life stages: young, middle age and fully grown (5 replicates for each stage). In what follows, these stages will be referred to as stage 1 , stage 2 and stage 3 , respectively. At stage 1 , measurements were carried out on plants from 4 up to 14 days old (age counting began with seed germination). Four-day-old plants were about $10 \mathrm{~cm}$ tall and had 2 small leaves (leaf numbering started from the base). Fourteen-day-old plants were about $35 \mathrm{~cm}$ tall and had 4 to 5 leaves. The whole plant was enclosed at this stage because it was not feasible to enclose a single leaf for a sufficiently long period without damaging it. This was due to the fast elongation rate of both leaves and stem. An almost fully grown 7th leaf (total length was about $80 \mathrm{~cm}$ ) of a 30 to 40 -day-old plant (about $120 \mathrm{~cm}$ tall) was partially enclosed (the top $55 \mathrm{~cm}$ ) during the experiments on leaves of stage 2 . At stage 3 , a fully grown leaf (either the 7 th, 8 th or 9th) of a fully grown maize plant (about $180 \mathrm{~cm}$ tall) was partially enclosed (the top $55 \mathrm{~cm}$ as well). After enclosing, the measurements on leaves of stage 2 and 3 were performed for about 5 days. More details about the plants and the enclosed leaf/leaves at the different plant developmental stages at which the experiments were carried out can be found in Table 1.

When the seeds had germinated, the small seedlings were transplanted in cylindrical 201 pots containing soil that consisted of a mixture of $75 \%$ silty clay loam and $25 \%$ sand (volume/volume). Plants were grown in the environmental chamber where the BVOC measurements were conducted. They were watered regularly to keep the soil moisture content around 35\%.

The dimensions of the environmental chamber were $3 \mathrm{~m} \times 2.6 \mathrm{~m} \times 2.2 \mathrm{~m}(\mathrm{~L} \times \mathrm{W} \times \mathrm{H})$. Light intensity and temperature were controlled automatically. Seven-hour-long dark periods were 
Table 1

Detailed information about the plants and the enclosed leaf/leaves at the different plant developmental stages at which the experiments were carried out. The BBCH code and AGDD (Accumulated Growing Degree-Days), two useful metrics for describing plant development, are explained in supplement S1.

\begin{tabular}{lllll}
\hline Stage & $\begin{array}{l}\text { Plant age } \\
\text { [days] }\end{array}$ & Enclosed leaf/leaves & BBCH code & $\begin{array}{l}\text { AGDD } \\
\text { [degree-days] }\end{array}$ \\
\hline 1 & $4-14$ & $\begin{array}{l}\text { first 2-5 leaves } \\
\text { (young) }\end{array}$ & $10-14$ & $122-274$ \\
2 & $30-40$ & $\begin{array}{l}\text { 7th leaf } \\
\text { (almost fully grown) }\end{array}$ & $17-19$ & $518-671$ \\
3 & $60-70$ & $\begin{array}{l}\text { 7th/8th/9th leaf } \\
\text { (fully grown) }\end{array}$ & $65-69$ & $976-1128$ \\
\hline
\end{tabular}

alternated by photoperiods of seventeen hours. Light was provided by a set of 40 Philips Green Power Production Led Modules (Lights Interaction Agro B V., Eindhoven, The Netherlands, model \#R/W 120) mounted at the environmental chamber ceiling. PPFD in the environmental chamber was varied stepwise, resulting in 6 light periods ranging from 0 to $600 \mu \mathrm{mol} \mathrm{m} \mathrm{m}^{-2} \mathrm{~s}^{-1}$ at the top of the plant enclosures (Fig. 2a, d and g). During the photoperiod, the temperature in the growth chamber was kept at $25{ }^{\circ} \mathrm{C}$ by an air cooling system. In the absence of light, temperature slowly decreased to around $23{ }^{\circ} \mathrm{C}$ as no additional heating was provided. Temperature in the enclosures varied depending on the light conditions from 23 to $27^{\circ} \mathrm{C}$.

\subsection{Dynamic flow-through enclosures}

Cylindrical dynamic flow-through enclosures were used for enclosing a whole maize plant or part of a single leaf (Fig. 1). The frame was made of aluminum bars and transparent polymethylmethacrylate (PMMA) rings and plates. It held a cylindrical $50 \mu \mathrm{m}$ thick PFA (perfluoroalkoxy Teflon) envelope (Norton, SaintGobain Performance Plastics, NJ, USA) which was 96\% transparent to photosynthetically active radiation (PAR). Two $1 / 4$ inch outer diameter PFA tubes were connected to each enclosure, one for supplying purge air (with flow rate $Q_{\text {in }}$ ) and the other for sampling BVOC-enriched air (with flow rate $Q_{\text {out }}$ ). The enclosures were equipped with a Teflon fan for efficient mixing of emitted BVOCs and purge air, a thermistor (type $10 \mathrm{k}$, NTC, Omega, UK) and a relative humidity sensor (type HIH-3610, Honeywell, NJ, USA) for continuously monitoring air temperature and relative humidity, respectively. Besides, a PAR sensor (type LI-190SA, LI-COR, USA) was fixed in the middle of the environmental chamber at the top height of the enclosures to track PPFD values on the plants or enclosed leaves.

Two enclosure configurations were used, depending on the enclosed biomass. Small shoots of plants of stage 1 were inserted in $22 \mathrm{~L}$ enclosures through a small opening (1 cm diameter) in the bottom foil of the enclosure and were left to grow inside until they touched the upper foil (Fig. 1, left). In this way emissions from shoots could be separated from emissions from roots and soil. In the second configuration, the same type of enclosure was fixed to a mast and the lower foil was replaced by an extension of the cylindrical envelope which was gently put around a leaf of stage 2 or stage 3 (enclosing the top $55 \mathrm{~cm}$ of the leaf) (Fig. 1, right). In this way, the total enclosure volume was enlarged to about $30 \mathrm{~L}$. The foil around the enclosed leaf was kept slightly loose to prevent mechanical damage of the leaf. In addition, an empty enclosure was used as a reference to measure the background VOC concentration.

\subsection{Gas exchange measurements, VOC sampling and quantification}

An oil free compressor with absorption dryer (DK50 $2 \times 2 \mathrm{~V} /$ $110 \mathrm{~S} / \mathrm{M} / 230 \mathrm{~V}$, EKOM, Germany) was used to provide air to the enclosures. Since air from the compressor had a much lower $\mathrm{CO}_{2}$ concentration (approx. $200 \mathrm{ppmv}$ ) than the ambient air, pure $\mathrm{CO}_{2}$ from a commercial gas bottle (Air products, $99.5 \%$ pure) was added
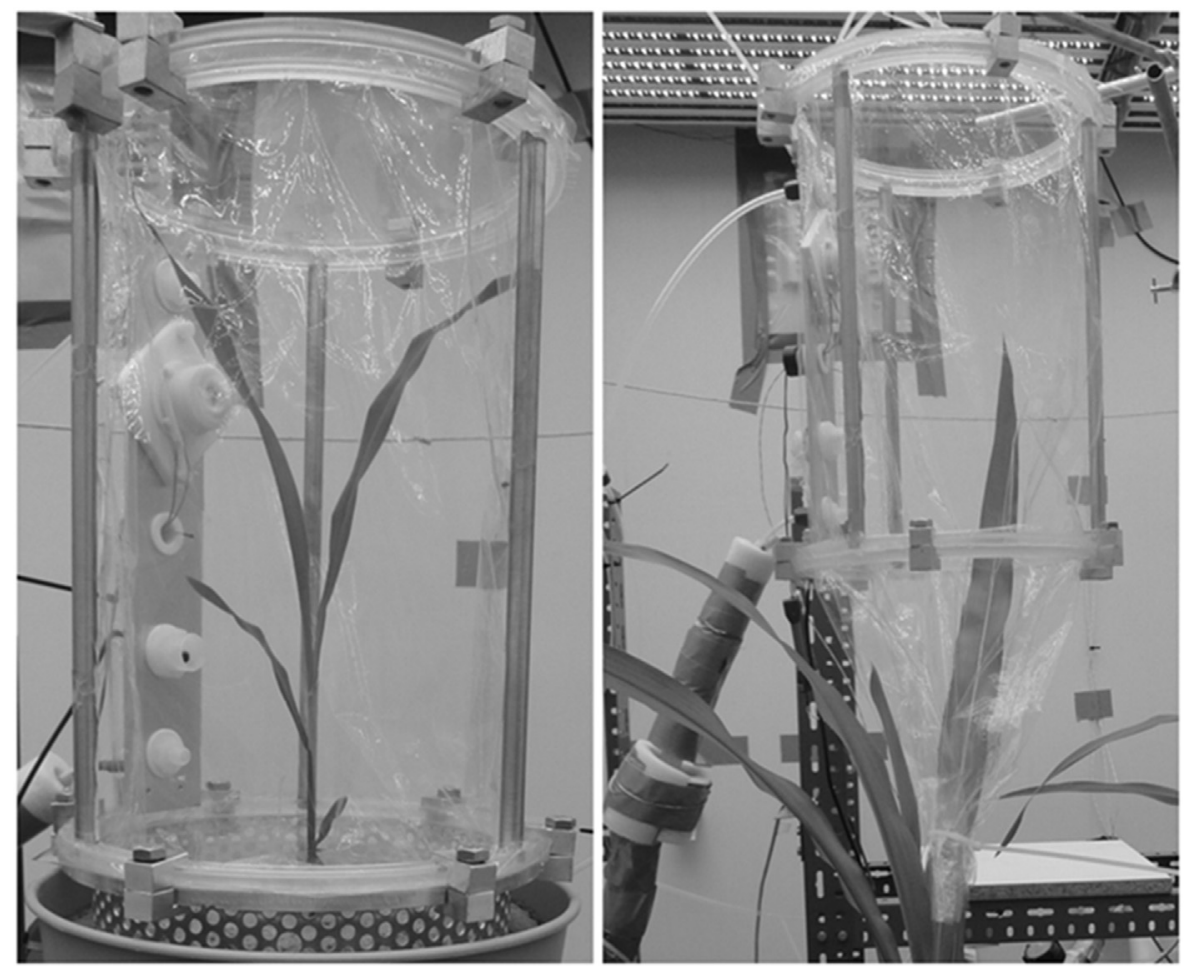

Fig. 1. Dynamic enclosure set-up for fully enclosed young maize plants (left) and for partially enclosed almost fully grown maize leaves (right). 

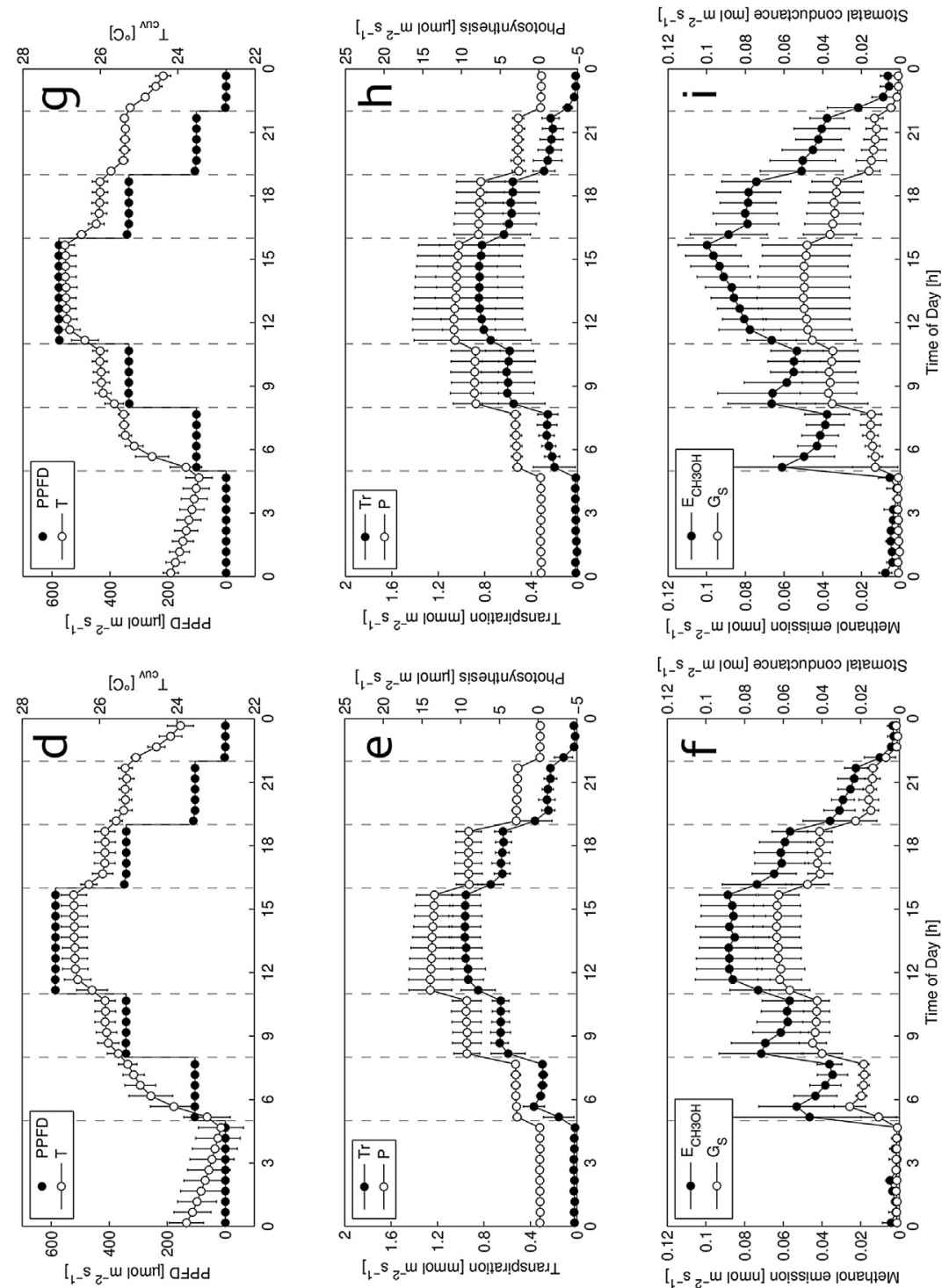

$\left[{ }^{1-} s_{2^{-}}\right.$m lom] esuetonpuos letemors
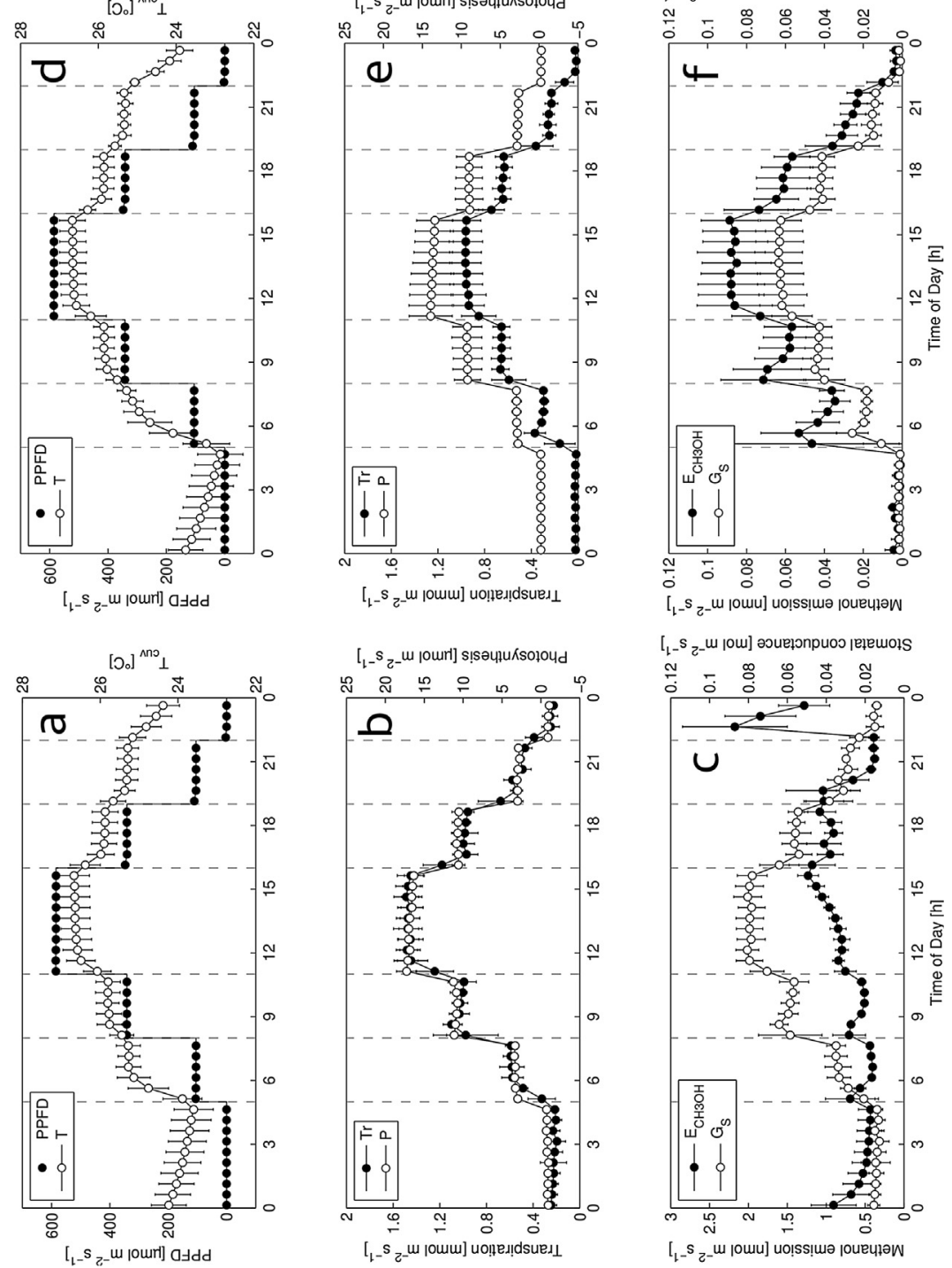

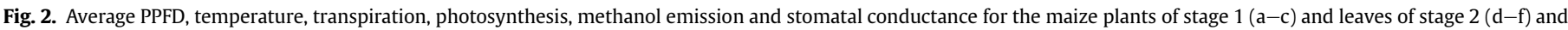

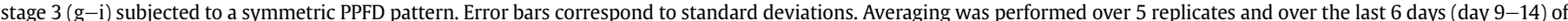

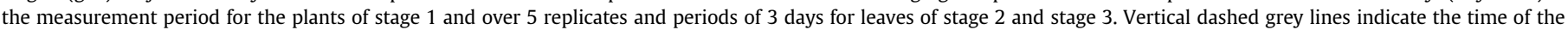
stepwise PPFD increases/decreases. 
to the air flow by means of a flow controller (MKS Instruments, Andover, MA, USA). An average concentration of $420 \mathrm{ppmv} \mathrm{CO}_{2}$ was maintained in the purge air flow all the time. Relative humidity was adjusted to about $40 \%$ by a homemade humidifier, as the relative humidity of the compressed/dried air was very low (about 5\%). Air was subsequently sent through a set of active charcoal filters (Airpel 10, Organosorb 10-CO, Desotec, Belgium) to scrub VOCs from the humidified air. To obtain equal flow rates for all the enclosures, the filtered air was then sent through a set of flow meters (F-102EIABD-55 V, 0-30 L min ${ }^{-1}$, Bronkhorst, The Netherlands), each followed by a ball valve (type SS-43S4, Swagelok, OH, USA) for manual adjustment of the flow rate $\left(Q_{\text {in }}\right)$ which was maintained at $5 \mathrm{~L} \mathrm{~min}^{-1}$ (at standard conditions of pressure $(1013.25 \mathrm{hPa}$ ) and temperature $(293 \mathrm{~K})$ ) for all individual enclosures. Q in was always much higher than $\mathrm{Q}_{\text {out }}$ (kept at $1.35 \mathrm{~L} \mathrm{~min}^{-1}$ ) and the overflow $\left(\mathrm{Q}_{\mathrm{in}}\right.$ $Q_{\text {out }}$ ) left the enclosure mainly through the open space around the enclosed stem or leaf. The pressure in the enclosures was less than $0.2 \mathrm{hPa}$ above ambient pressure.

BVOC mixing ratios were measured using a conventional quadrupole-based hs-PTR-MS (Proton Transfer Reaction-Mass Spectrometer, Ionicon Analytik G.m.b.H., Innsbruck, Austria), which is a very sensitive instrument for real time monitoring of trace volatile organic compounds (Lindinger et al., 1998; Ellis and Mayhew, 2014). The PTR-MS was operated at a drift tube pressure of $2.1 \mathrm{hPa}$, a drift tube temperature of $60^{\circ} \mathrm{C}$ and a drift tube voltage of $600 \mathrm{~V}$, resulting in a value for $\mathrm{E} / \mathrm{N}$ (ratio of the electric field $\mathrm{E}$ to the gas number density $\mathrm{N}$ ) in the drift tube of $130 \mathrm{Td}(1$ $\mathrm{Td}=10^{-17} \mathrm{~V} \mathrm{~cm}^{2}$ ). Furthermore, the inlet line of the PTR-MS was kept at $60^{\circ} \mathrm{C}$. Ions at $\mathrm{m} / \mathrm{z} 33$ and isotopes of the proton hydrates at $\mathrm{m} / \mathrm{z} 21\left(\mathrm{H}_{3}^{18} \mathrm{O}^{+}\right)$and $\mathrm{m} / \mathrm{z} 39\left(\mathrm{H}_{5}^{16} \mathrm{O}^{18} \mathrm{O}^{+}\right)$as well as some other BVOC related ion species were followed sequentially. The ion signal at $\mathrm{m} / \mathrm{z}$ 33 is known to be due to both protonated methanol $\left(\mathrm{H}^{+} . \mathrm{CH}_{3} \mathrm{OH}\right)$ and the molecular oxygen isotope ${ }^{17} \mathrm{O}^{16} \mathrm{O}^{+}$. The contribution of the latter ion signal, however, cancels when determining the net ion signals (plant/leaf enclosure - reference enclosure) for calculating the methanol fluxes. The ion signal at $\mathrm{m} / \mathrm{z} 39$, which is used here to calculate water vapor fluxes, could in principle contain contributions of fragment ions from BVOCs as well. However, net ion signals at $\mathrm{m} / \mathrm{z} 39$ were always significantly higher than net VOC-related ion signals at other $\mathrm{m} / \mathrm{z}$ values (except for $\mathrm{m} / \mathrm{z} 33$ ), which suggests that the contribution of VOCs to $\mathrm{m} / \mathrm{z} 39$ in our study must have been very small.

The total PTR-MS cycle time was $44 \mathrm{~s}$ and during this time, the ion signal at $\mathrm{m} / \mathrm{z} 33$ was measured for $10 \mathrm{~s}$. Additionally, PTR-MS calibrations were performed every 5 days by using a gravimetrically prepared mixture of methanol (1.07 ppmv) and other BVOCs in nitrogen (Apel-Riemer Inc., Denver, CO, USA), with a certified accuracy of $5 \%$. The calibration gas was further diluted with zero air, generated by sending ambient air through a catalytic converter (Parker ${ }^{\circledR}$ ChromGas $^{\circledR}$ Zero Air Generator, model 1001, Parker Hannifin Corporation, Haverhill, MA, USA) to obtain mixing ratios in the 0-12 ppbv range for methanol. The methanol detection limit was estimated at $170 \mathrm{pptv}$ (for an integration time of $10 \mathrm{~s}$ ).

The calibration of the water vapor mixing ratio in the sampled air versus the $\mathrm{m} / \mathrm{z} 39$ ion signal was performed on average every 5 days by using a dew point generator (LI-COR 610, LI-COR, Lincoln, Nebraska, USA). Besides, carbon dioxide $\left(\mathrm{CO}_{2}\right)$ mixing ratios were determined with a LI-7000 non-dispersive infrared gas analyzer (LI-COR, Lincoln, Nebraska, USA).

In order to perform flux measurements with sufficient time resolution, the number of sampling enclosures was limited to three: two plant or leaf enclosures and one empty reference enclosure. Consequently, not all plant replicates were investigated simultaneously, but they were studied under the same experimental conditions. The diurnal cycle of BVOC emissions was investigated by sequentially sampling air from each enclosure for a duration of $10 \mathrm{~min}$, resulting in a measurement cycle time of 30 min. This sampling procedure was automated by a Labview ${ }^{\mathrm{TM}}$ (National Instruments Corporation, Austin, Texas, USA) controlled manifold system. The first and the last minute of the $10 \mathrm{~min}$ sampling period were not considered for the flux calculations to avoid measurement errors due to switches between enclosures. Measurements performed at the day of enclosure were not taken into account as they might have been influenced by stress-induced emissions. Methanol emission rates $\left(\mathrm{E}_{\mathrm{CH} 3 \mathrm{OH}}\right)$, transpiration rates $(\mathrm{Tr})$ and net photosynthesis rates $(\mathrm{P})$, all expressed in $\mathrm{mol} \mathrm{m}^{-2} \mathrm{~s}^{-1}$, were obtained by using the following equations:

$$
\begin{aligned}
& E_{C H 3 O H}=\left(X_{C H 3 O H, P E}^{a i r}-X_{C H 3 O H, R E}^{a i r}\right) \times \frac{Q_{i n}}{R T_{r e f}} \times \frac{1}{L A} \\
& T r=\left(X_{H 2 O, P E}^{a i r}-X_{H 2 O, R E}^{a i r}\right) \times \frac{Q_{i n}}{R T_{r e f}} \times \frac{1}{L A} \\
& P=\left(X_{C O 2, P E}^{a i r}-X_{C O 2, R E}^{a i r}\right) \times \frac{Q_{i n}}{R T_{r e f}} \times \frac{1}{L A}
\end{aligned}
$$

In these equations $\mathrm{X}_{\mathrm{A}, \mathrm{PE}}^{\mathrm{air}}$ and $\mathrm{X}_{\mathrm{A}}^{\mathrm{air}} \mathrm{RE}$ are the mole fractions of compound $\mathrm{A}$ (either $\mathrm{CH}_{3} \mathrm{OH}, \mathrm{H}_{2} \mathrm{O}$ or $\mathrm{CO}_{2}$ ) in the sampled air flows from the plant/leaf and reference enclosures, respectively. $\mathrm{Q}_{\text {in }}\left[\mathrm{Pa} \mathrm{m}^{3} \mathrm{~s}^{-1}\right.$ ] and $T_{\text {ref }}(293 \mathrm{~K})$ are the incoming flow rate (measured with the mass flow meter) and the reference temperature of the mass flow meter, respectively. $\mathrm{R}$ is the ideal gas constant $\left(8.314 \mathrm{~J} \mathrm{~mol}^{-1} \mathrm{~K}^{-1}\right)$ and LA $\left[\mathrm{m}^{2}\right]$ is the enclosed leaf area.

The total leaf conductance $G_{\text {tot }}\left[\mathrm{mol} \mathrm{m}^{-2} \mathrm{~s}^{-1}\right]$ to water vapor was estimated by the following formula (Pearcy et al., 1989):

$$
G_{t o t}=\frac{T r}{\left(X_{H 2 O}^{\text {leaf }}-X_{H 2 O, P E}^{a i r}\right)}
$$

in which $\mathrm{X}_{\mathrm{H} 2 \mathrm{O}}^{\text {leaf }}$ is the water vapor mixing ratios in the leaf's intercellular spaces. This mixing ratio is given by Eq. (3), in which $\mathrm{p}_{\text {sat, }}$ Tleaf $[\mathrm{Pa}]$ is the saturation vapor pressures of water at $\mathrm{T}_{\text {leaf. }}$

$X_{H 2 O}^{\text {leaf }}=\frac{p_{\text {sat,Tleaf }}}{101325}$

As the position of the leaves in the enclosures continuously changed due to the fast growth rate of the young plants, leaf temperature measurements with IR leaf temperature sensors or a thermocouple were experimentally not feasible. Therefore leaf temperature was assumed to be equal to air temperature. The leaf conductance $\mathrm{G}_{\text {tot }}$ in Eq. (2) includes stomatal conductance, boundary layer conductance and cuticular conductance. In our setup, however, boundary layer conductance and the difference between air and leaf temperature were assumed to be limited by the purge air flow, as well as by the efficient mixing of the air in the enclosure by the Teflon fan. By neglecting cuticular conductance, stomatal conductance, $\mathrm{G}_{\mathrm{S}}$, in our experiments was therefore approximated by total leaf conductance.

\subsection{Leaf area estimation}

Due to the fast growth of maize plants of stage 1, daily leaf area estimations were needed. Since opening the enclosure could have damaged the plants and could have induced stress related BVOC emissions, they were kept enclosed during the entire 10-day measurement period. During this period, leaf area was determined daily by visual estimation of the maximum width $W$ and length $L$ of 
the individual leaves without opening the enclosure. The leaf area was estimated as the product of $\mathrm{W}$ and $\mathrm{L}$, multiplied by a factor 0.78 . This factor was experimentally determined using all leaves of a set of 5 non-enclosed plants which were grown in similar conditions as the enclosed ones and is in good agreement with the literature (Mokhtarpour et al., 2010). At the end of the measurement period, the total leaf area was measured accurately (Harley et al., 2007) after the removal of all the leaves from the plant. The data obtained agreed well with the visually estimated leaf dimensions just before disclosing the plant. Fresh weight of the leaves was measured immediately after disclosure and their dry weight was obtained after at least $48 \mathrm{~h}$ of drying in an oven at $75^{\circ} \mathrm{C}$ until all water was evaporated and a constant weight was reached.

Leaf area estimations of partially enclosed leaves of stage 2 and stage 3 were also performed on a daily basis. Accurate leaf area and fresh weight measurements were also performed immediately after removing the leaves from the enclosures. For the dry weight measurements, the same procedure was followed as for plants of stage 1.

\subsection{Methanol emission modelling}

There is strong evidence that leaf-level emissions of highly water-soluble species, such as methanol, are controlled by stomatal conductance (Harley, 2013). Consequently, those emissions can only be properly described by a model that predicts the response of the emissions to variations in stomatal conductance, such as the one of Niinemets and Reichstein (Niinemets and Reichstein, 2003a; 2003b). Therefore, flux data for the leaves of stage 2 and 3 and maize plants of stage 1 have been evaluated against the dynamic BVOC emission model of Niinemets and Reichstein, using a predefined methanol production function.

The experimental data for stomatal conductance, temperature and PPFD were used as input for the model. By lack of specific data for Zea Mays L., the leaf structural parameters for Phaseolus vulgaris L. as reported in (Niinemets and Reichstein, 2003b) were used instead. In accordance with Niinemets and Reichstein (2003b), our model results were not strongly affected by changes in those leaf structural parameters.

Although some studies indicate that methanol production in leaves is independent of PPFD (Oikawa et al., 2011; Harley et al., 2007) and attribute the PPFD dependence of the emissions to the effect of PPFD on stomatal conductance, we considered a more general approach by using a similar light and temperature dependence for the methanol production function as in the leaf level methanol emission algorithm in the MEGANv2.1 model (Stavrakou et al., 2011). This methanol production function PF is given by:

$P F=\varepsilon \cdot \gamma_{P T}$

where $\varepsilon$ is the rate of methanol production at the standard leaf temperature and PPFD conditions of $303 \mathrm{~K}$ and $1000 \mu \mathrm{mol} \mathrm{m}{ }^{-2} \mathrm{~s}^{-1}$, respectively. $\gamma_{\mathrm{PT}}$, the leaf level temperature and light response factor, is given by:

$\gamma_{P T}=(1-L D F) \cdot \gamma_{T-l i}+L D F \cdot \gamma_{P} \cdot \gamma_{T-l d}$

LDF is the light dependent fraction of the emissions, $\gamma_{P}$ is the light dependent response factor and $\gamma_{\mathrm{T} \text {-ld }}$ and $\gamma_{\mathrm{T}-\mathrm{li}}$ are the temperature response factors of the light-dependent and the lightindependent methanol emissions, respectively. The explicit formulas for these response factors can be found in Stavrakou et al., 2011. A value of $0.08 \mathrm{~K}^{-1}$ was used for the $\beta$ parameter in the exponential temperature dependence of $\gamma_{T-l i}$ (Stavrakou et al., 2011; Harley et al., 2007). More details about the equations used for modelling methanol fluxes and model options are given in Supplement S1.

\section{Results and discussion}

\subsection{Daytime methanol production driver(s) for young maize plants}

The daytime methanol emission pattern for the maize plants of stage 1 was characterized by a steadily increasing emission for most of the day, upon which transient emissions were superimposed after each increase in PPFD (Fig. $2 a-c$ ). According to the dynamic BVOC emission model of Niinemets and Reichstein (Niinemets and Reichstein, 2003a; 2003b), these transient changes are due to a transfer of methanol from the non-specific liquid storage pool in the leaves to the gaseous pool, following a sudden increase in stomatal conductance. The transient changes last until a new equilibrium between the pools is settled. The first transient increase of methanol emission, along with a stepwise increase of Gs, Tr and P, was observed after the plants had been exposed to a PPFD of approximately $100 \mu \mathrm{mol} \mathrm{m} \mathrm{m}^{-2} \mathrm{~s}^{-1}$ (at 5 a.m.) following a dark period of $7 \mathrm{~h}$. Similar bursts in the morning have been reported previously by many investigators (MacDonald and Fall, 1993; Nemecek-Marshall et al., 1995; Hüve et al., 2007; Harley et al., 2007; Folkers et al., 2008). Small transient peaks of methanol emission were also noticed at every further stepwise increase in PPFD (at 8 a.m. and 11 a.m.). This has also been observed in laboratory studies of Sorghum bicolor and Pinus taeda (Harley et al., 2007) and is related to accompanying stepwise increases in stomatal conductance.

Although a symmetric light pattern was maintained in the environmental chamber, a strong asymmetry was observed in the methanol emission pattern (Fig. 2a and c). Indeed, for all constant PPFD periods between 5 a.m. and 4 p.m., the transient methanol emission peaks were followed by gradual increases in methanol emission. Moreover, the rate of increase of the emissions became larger with time. The decrease in PPFD at 4 p.m. resulted in a decrease in methanol emissions, which was again followed by a slightly upward trend during this constant PPFD period. Consequently, the average methanol emission at $350 \mu \mathrm{mol} \mathrm{m}^{-2} \mathrm{~s}^{-1}$ in the afternoon (approximately $1.0 \mathrm{nmol} \mathrm{m}-2 \mathrm{~s}^{-1}$ ) was about twice as large as the emission at the same PPFD level before noon (approximately $0.5 \mathrm{nmol} \mathrm{m} \mathrm{m}^{-2} \mathrm{~s}^{-1}$, not considering the transient emission values at the start of this constant PPFD period). This upward trend could be explained by an increased methanol production over the day, possibly related to the diurnal evolution of plant growth rate (which is known to be species dependent (Hüve et al., 2007)) or to a diurnal variability in PME activity. A decrease in methanol emission was also noticed after the next decrease in PPFD (at 7 p.m.), albeit with some delay. But now the emissions showed a downward trend and finally reached a value close to the one at the end of the dark period ( 5 a.m.).

The continuous increase in methanol emission during the period of maximal PPFD suggests that the methanol production has not yet arrived at a maximum before the decrease in PPFD at 4 p.m. (Fig. 2c). To find out for how long this rise in methanol emission would continue at constant maximal PPFD conditions, a new experiment was performed with similar plant material in which the period of maximal PPFD was prolonged by $6 \mathrm{~h}$ (up to $10 \mathrm{p} . \mathrm{m}$.), after which PPFD dropped to zero. The results of this experiment are shown in Fig. 3. Whereas the methanol emission rate in both experiments was very similar within the photoperiod between 5 a.m. and 4 p.m., it continued to increase smoothly in the experiment with the extended period of maximum PPDF (Fig. 3c), peaked around 7 p.m. and then decreased towards the end of the maximum PPFD period. Transpiration, photosynthesis and stomatal 

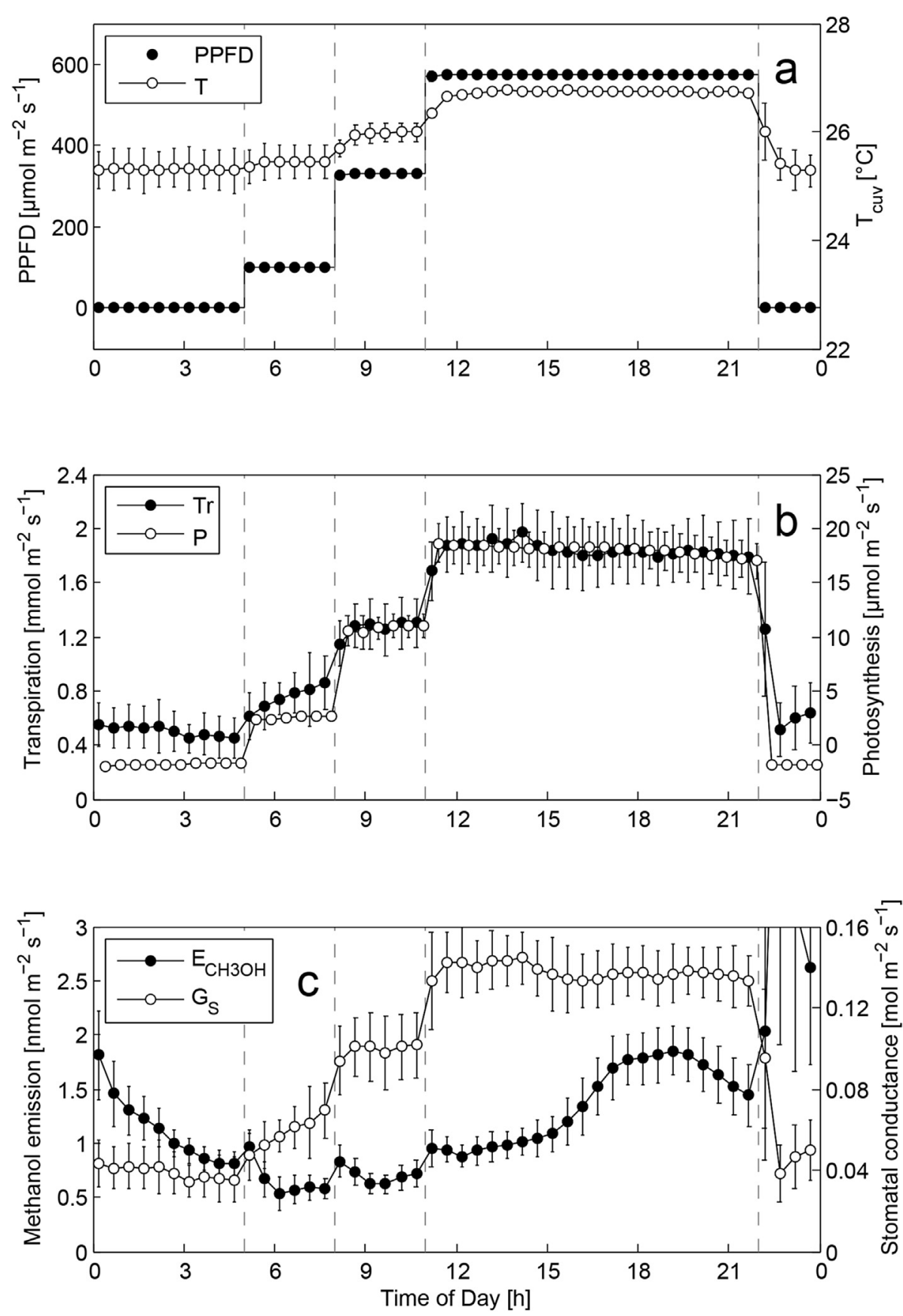

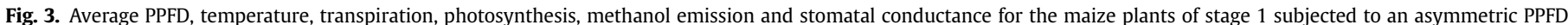

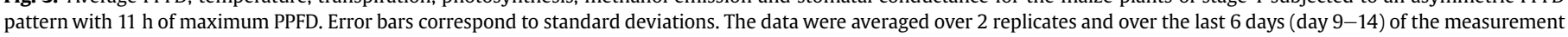
period. Vertical dashed grey lines indicate the time of the stepwise PPFD increases/decreases.

conductance hardly varied during this entire period of maximum PPFD. The variation of methanol emission during this period was thus clearly not controlled by the stomata, but probably by changes in the methanol production rate. These changes are possibly induced by a temporal variability in growth rate or PME activity.

\subsection{Is methanol production for almost fully grown and fully grown} maize leaves controlled by PPFD?

Maize leaves of stage 2 and stage 3 showed stepwise changes of methanol emission following stepwise changes in PPFD (Fig. 2d, f, $2 \mathrm{~g}$ and $2 \mathrm{i}$ ). Whereas the methanol emissions followed very closely transpiration and stomatal conductance for the leaves of stage 2 , a gradual increase in the emissions during the maximum PPFD period was noticed for the leaves of stage 3 . This results in an asymmetric emission pattern under a symmetric PPFD pattern. Small methanol emission bursts, resulting from changes in stomatal conductance, were superimposed upon the stepwise increase in emission for leaves of both stages 2 and 3 when PPFD increased (at 5 a.m. and 8 a.m.).

Recent studies by Oikawa et al. on Lycopersicon esculentum (Oikawa et al., 2011) indicate that methanol production from that plant species is independent of PPFD, and variation of the methanol emissions with PPFD is related to the impact of this parameter on 
stomatal conductance. According to the model of Niinemets and Reichstein, however, changes in stomatal conductance at constant methanol production should only lead to transient methanol emission changes and not to stepwise increases or decreases. Possible explanations for the stepwise changes in methanol emission with PPFD for the leaves of stages 2 and 3 could be 1) that methanol production is actually controlled by PPFD for those leaves and/or 2) that methanol mainly comes with the transpiration stream which carries methanol from other parts of the plant (roots, stem, fruits, flowers ...) to the leaves.

In order to find out whether a PPFD dependence of the methanol production could explain our observations, we applied the Niinemets and Reichstein model using the generalized production function described in Section 2.5 (Eq. (4)). In a study on leaf-level methanol emissions from different plant species, Harley et al. (2007) found a nice correlation between modelled and measured methanol data by using a production function that varied exponentially with temperature. This production function is obtained by setting the light dependent fraction of the emission (LDF in Eq. (5)) to zero. We have used it in a first step to evaluate our measurements for the maize leaves of stage 2 against the model. A standard methanol production rate $\varepsilon$ of $6.3 \times 10^{-11} \mathrm{~mol} \mathrm{~m}^{-2} \mathrm{~s}^{-1}$ was obtained by minimizing the absolute difference between the accumulated measured and modelled emissions over the whole day. The model result is shown in Fig. 4 (full gray line) together with the measurements. The model largely overestimates the emission burst following the dark/light transition and the nighttime emissions preceding this burst. Moreover, the variation of the methanol emissions with PPFD at equilibrium conditions is not well reproduced either. Harley et al. (2007) reported that any change to the model that retards the rate at which the liquid methanol pool comes into equilibration improved the model fit to their data. One way to extend this time for equilibration in the model is by increasing the value for the liquid water content (LWC) of the leaves. They found a better agreement between their modelled and observed transient methanol emissions by multiplying this LWC value by a factor 4 . By using the same multiplication factor, the emission bursts in our experiments were also better simulated by the model. Nevertheless, the modelled daily emission pattern (dashed gray line) still agreed poorly with the measurements. Moreover, as Harley et al. (2007) pointed out in their paper, this way of extending the pool equilibration time cannot be justified as it leads to unrealistically high values for the liquid water content of the leaves.

Subsequently, a light and temperature dependent production function was applied and in a first stage LDF was kept at the prescribed value of 0.8 as in the MEGANv2.1 model. An optimal value for $\varepsilon$ of $1.11 \times 10^{-10} \mathrm{~mol} \mathrm{~m}^{-2} \mathrm{~s}^{-1}$ was obtained by a least squares fit of the model to the half hourly emission measurements (Fig. 4, solid black line). Even though the modelled emissions show a clear improvement with respect to those obtained by using the temperature-only production function, nighttime emissions and the morning peak are still too high compared to the measurements. This is due to an overestimation of the light-independent production (i.e. an underestimation of the LDF value), which results in a too high value of the methanol liquid pool size before the dark/light transition. An overnight light-independent methanol production is, however, necessary to obtain a sufficiently high liquid pool size to be able to simulate the peak in the morning. This is clearly shown in Fig. 4 (dot-dashed black line) for the model run with $\mathrm{LDF}=1$ (optimized $\varepsilon$ is $1.24 \times 10^{-10} \mathrm{~mol} \mathrm{~m}^{-2} \mathrm{~s}^{-1}$ ).

Therefore, a logical step was to run the model over a large range of both $\varepsilon$ and LDF. The least squares fit of the model to the half hourly measurements resulted in values of $\varepsilon$ and LDF of $1.18 \times 10^{-10} \mathrm{~mol} \mathrm{~m}^{-2} \mathrm{~s}^{-1}$ and 0.90 , respectively (Fig. 4, dashed black line). Although the modelled emissions for these optimized $\varepsilon$ and LDF values show a fair agreement with the observations, some minor observed features such as the small emission burst following the PPFD increase at 8 a.m. and the slow decrease of the emissions after every decrease in PPFD, still cannot be well reproduced. In conclusion, the results clearly indicate that the addition of a PPFD dependence of the methanol production function was definitely required to explain the observed fluxes.

A least squares fit of the model to the half hourly emission

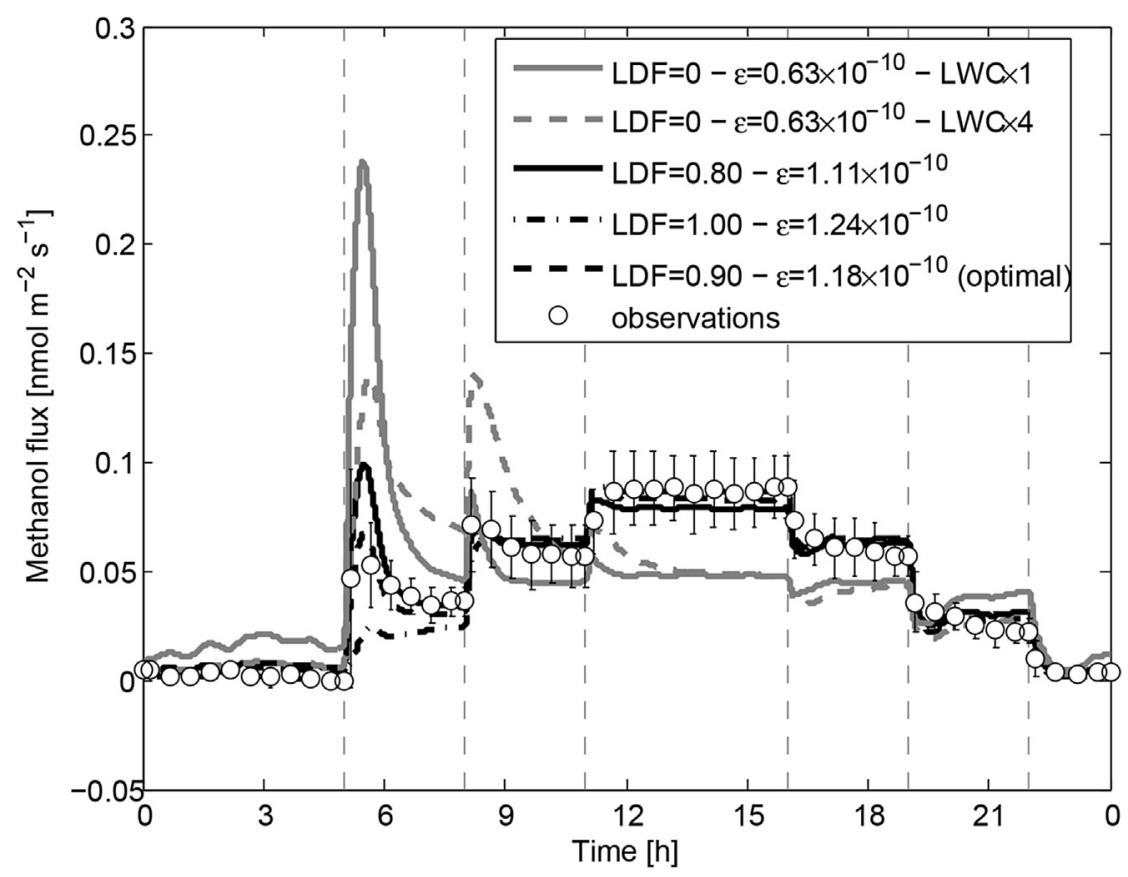

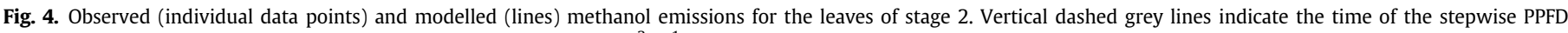
increases/decreases. LDF is dimensionless and $\varepsilon$ is expressed in $\mathrm{mol} \mathrm{m}^{-2} \mathrm{~s}^{-1}$. See text for further details. 
measurements of leaves of stage 3 resulted in optimal values of $1.28 \times 10^{-10} \mathrm{~mol} \mathrm{~m}^{-2} \mathrm{~s}^{-1}$ and 0.90 for $\varepsilon$ and LDF, respectively (data not shown). This LDF value is the same as the one obtained for the leaves of stage 2 . Although the modelled emissions still lie within the error bars of the observations, the agreement is less good than for the leaves of stage 2 . This is mainly due to the steady increase of the emissions at a maximum PPFD (Fig. 2i). The reason for this is unclear, but might be related to cell degradation as the leaves of stage 3 were close to undergoing chlorosis/senescence, a plant developmental stage which is accompanied by increased methanol emissions.

Fitting the model to the methanol emissions from maize plants of stage 1 did not result at all in reasonable predictions of the measurements (Fig. 5). Indeed, whereas the model results in nice stepwise emission changes during the day, upon which transient effects due to sudden stomatal changes are superimposed, we clearly observed strong variations in emissions at constant light, temperature and stomatal conductance. It is clear that in order to obtain a better agreement between modelled and measured emissions, the production of methanol from leaves of stage 1 must be modulated by some other parameter (e.g. diurnal variability in leaf growth rate or in PME enzyme activity). We were not able to identify this parameter on the basis of our measurements.

\subsection{Guttation as a potential source of nighttime methanol emission from young maize plants}

The most striking feature of the methanol emission pattern from maize plants of stage 1 (Fig. 2c) was the presence of a large peak following the light/dark transition at 10 p.m., which, to the best of our knowledge, has never been mentioned in the literature. In this paper, we put forward the hypothesis that the evaporation of methanol from guttation fluid, coming out of the tips and edges of the plant's young leaves through hydathodes, is a possible cause for this nighttime peak. Guttation is a common process for young maize plants (Joachimsmeier et al., 2011) and occurs when transpiration reduces after stomatal closure in dark conditions (Singh, 2013). Shortly after turning off the lights in the growth chamber, guttation droplets were indeed found to form on maize leaves of stage 1 on several occasions.

In order to strengthen our hypothesis of guttation as a pathway for methanol emission, guttation droplets from non-enclosed maize plants in the environmental chamber were collected with a Teflon syringe (Torvic, $20 \mathrm{~mL}$ ) and injected in a similar enclosure as the reference enclosure described in Section 2.2. The only difference was that a perforation of $4 \mathrm{~mm}$ in diameter was made in the top foil of the enclosure to allow the injection of the fluid. Moreover, purge flow, temperature and PPFD conditions were similar as for the plant emission measurements. Methanol was indeed found to be present in the guttation fluid. The cumulative mass of methanol exiting the guttation fluid, normalized with respect to the total mass of the injected guttation fluid, is shown as a function of time after injection in Fig. 6.

The mass mixing ratio of methanol in the guttation fluid was found to be $(3.3 \pm 1.1) \times 10^{-7}(n=5)$. The cumulative mass of evaporated water, again normalized with respect to the total mass of the injected guttation fluid, is also shown in Fig. 6. Note that the water mass mixing ratio in the guttation fluid is close to 1 , indicating that the latter is mainly composed of water. Furthermore, methanol inside the injected liquid completely vaporized within $20 \mathrm{~min}$, whereas it took water (from the injected droplets) almost an hour. This difference in temporal evolution of the cumulative mass mixing ratio of water and methanol reflects the difference in volatility between the two compounds but may also be influenced by other factors such as the concentrations of methanol and water vapor in the purge air flow, and temperature and turbulence in the enclosure. The difference in volatility between methanol and water also suggests that part of the methanol in the guttation droplets may already have escaped the liquid phase before the droplets were collected, since it took some time (about 1-1.5 h) for collectable

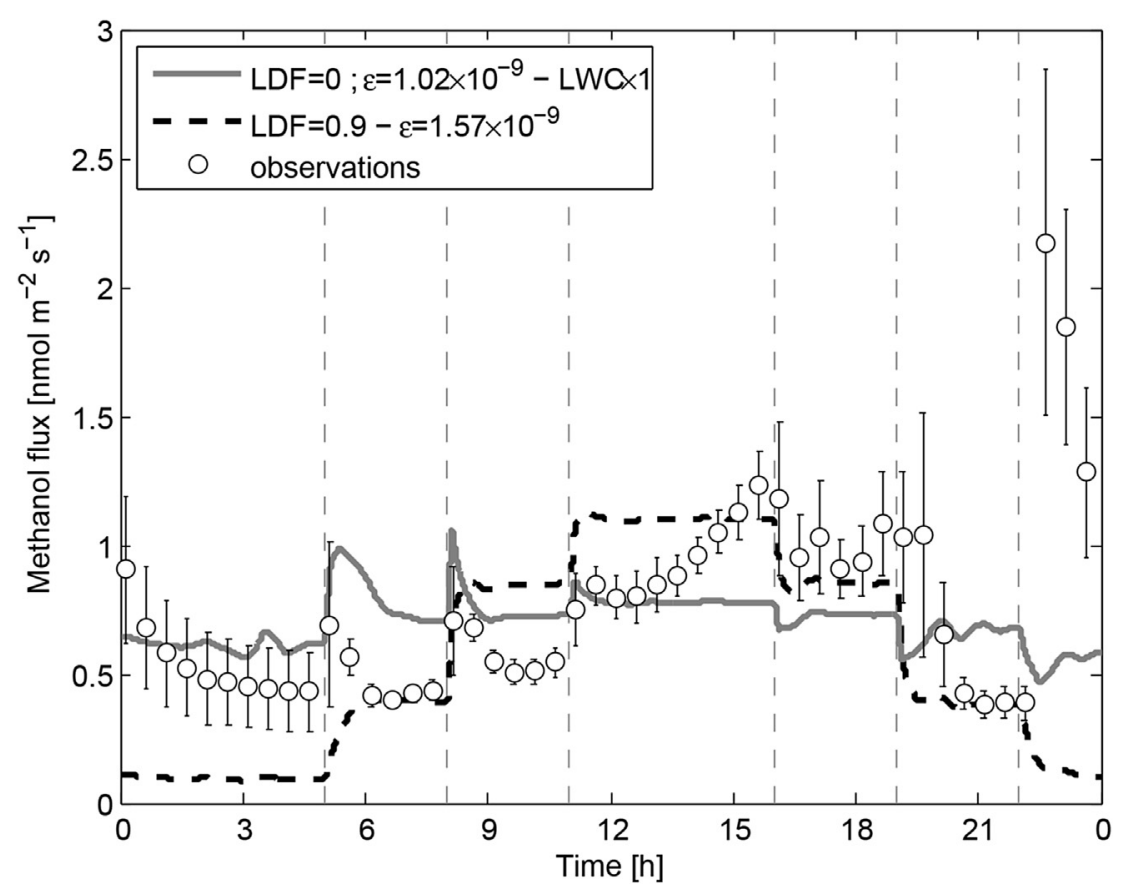

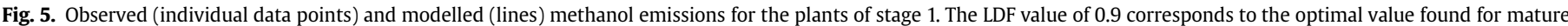

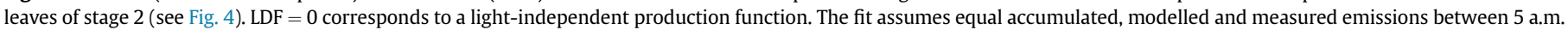
and 10 p.m.. Vertical dashed grey lines indicate the time of the stepwise PPFD increases/decreases. LDF is dimensionless and $\varepsilon$ is expressed in mol $\mathrm{m}^{-2} \mathrm{~s}^{-1}$. 

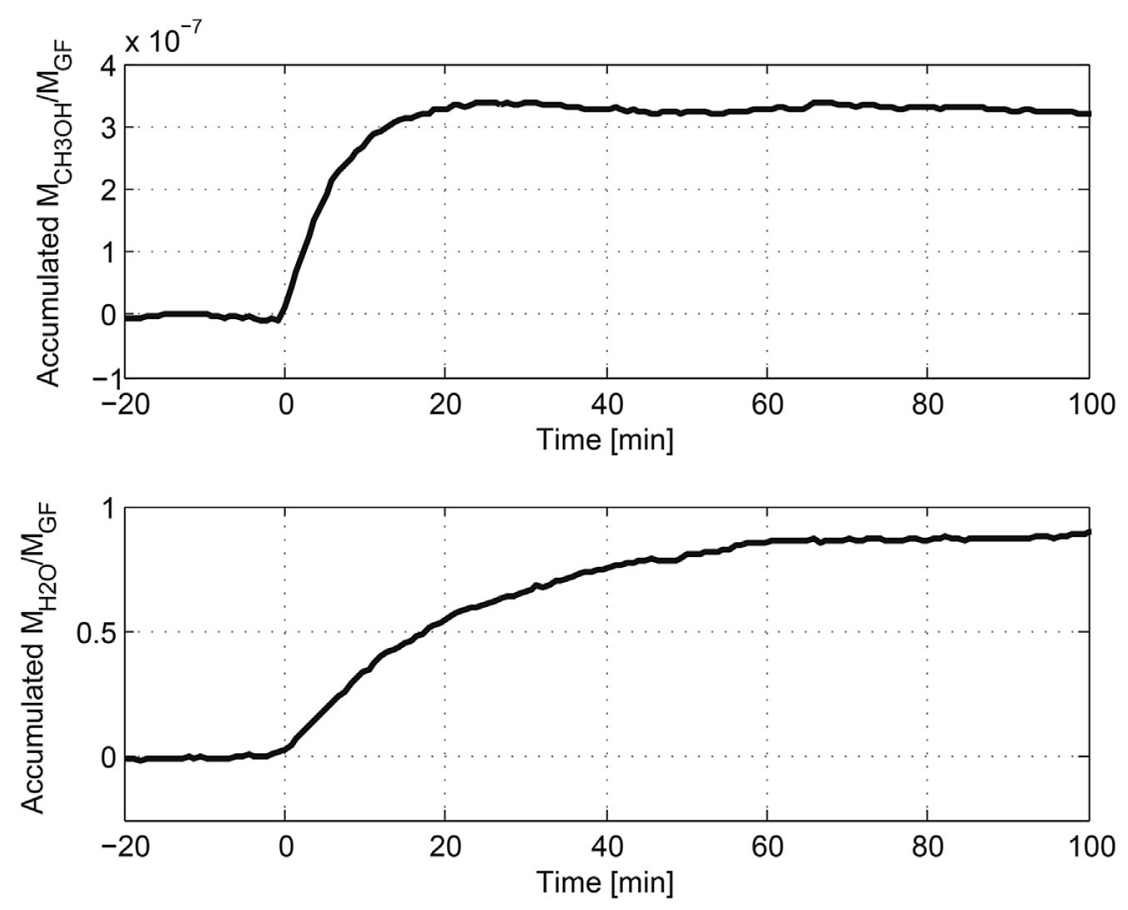

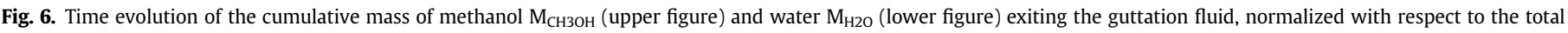
mass of the injected guttation fluid $\mathrm{M}_{\mathrm{GF}}$, after injection of the guttation fluid in the enclosure.

droplets to form and for the involved scientists to collect a sufficient number of them (approximately $0.5 \mathrm{~g}$ of guttation fluid). Consequently, the experimentally obtained value for the methanol mass mixing ratio in the guttation fluid could be considered as a lower limit. This might explain why the large increase in methanol emission following light/dark transition in Fig. $2 \mathrm{c}$ is not accompanied by a noticeable increase in the flow of water vapor (Fig. 2b). During the experiments with young maize plants subjected to an asymmetric PPFD pattern (Fig. 3), however, a small increase in the emission of water vapor was noticed after the light/dark transition. This is probably due to a more intense guttation as a result of the larger decrease in PPFD, which also explains the higher nighttime peak value for methanol emissions (Fig. 3c).

In order to find out whether methanol was also present in the guttation fluid of other crop species than maize, similar experiments were carried out with winter wheat (Triticum aestivum L.). It turned out that young winter wheat plants also showed strong guttation and enhanced methanol emissions following light/dark transitions (data not shown). The methanol content of the guttation fluid of 2 sets of 30 young wheat plants (5-6 days after germination) was determined in a similar way as for maize. The experiment resulted in values of $2.5 \times 10^{-7}$ and $4.3 \times 10^{-7}$ for the mass mixing ratio of methanol in the guttation fluid, which lie well within the range of values obtained for maize. Further research on other plant species is definitely required in order to find out whether methanol emission by the guttation pathway is a general mechanism in nature.

The intensity of the large nighttime methanol emission peak appeared to be maximal at the beginning of the six-day period over which the data were averaged (from day 9 to day 14 with respect to seed germination). It then decreased quasi linearly at an average rate of $12 \%$ per day, as reflected by the large error bar on the averaged peak values (Fig. 2c). This decrease of guttation intensity with time is in line with previous observations on strawberry leaves (Fragaria $x$ ananassa Duch.). These showed that, with time, the water pores in the hydathodes get occluded by shield-like plates, which are presumably comprised of epicuticular waxes and substances secreted through the hydathodes (Takeda et al., 1991). Moreover, field studies on agricultural crop species have shown that guttation frequency is particularly high in the early growth stages of the crops (Joachimsmeier et al., 2011).

For plants up to 8 days old (and even 10 days for one of the replicates), a transient methanol peak also occurred after the light intensity decreased from 350 to $100 \mu \mathrm{mol} \mathrm{m} \mathrm{m}^{-2} \mathrm{~s}^{-1}$ (data not shown). The hypothetical assignment of the latter peak to the guttation phenomenon is endorsed by the occasional observation of guttation droplets when maize plants of stage 1 were suddenly subjected to lower non-zero PPFD levels.

Beside guttation, other mechanisms for the nighttime methanol emission from plants of stage 1 cannot a priori be excluded. Since methanol emission has been associated with leaf growth (Hüve et al., 2007), a possible contribution to the nighttime methanol peak due to a transient increase in leaf growth following light/dark transitions (Poiré et al., 2010) might be considered. Moreover, in addition to high nighttime methanol emissions, accounting for as much as $30 \%$ of the total diurnal emissions, non-negligible nighttime values were obtained for $G_{s}$ and $\operatorname{Tr}$ as well (Fig. 2b and c). Nighttime emissions, co-occurring with non-negligible stomatal conductance and/or transpiration rates have been reported previously for some other plant species such as Populus deltoides (Harley et al., 2007), Gossypium hirsutum (Hüve et al., 2007) and Fagus sylvatica (Hüve et al., 2007; Folkers et al., 2008; Schade et al., 2011). Nighttime transpiration due to incomplete stomatal closure has also been reported for many C3 and C4 species (Caird et al., 2007). Therefore, a rather constant non-negligible stomatal conductance during the dark period, as observed in our experiments $\left(0.02 \mathrm{~mol} \mathrm{~m}^{-2} \mathrm{~s}^{-1}\right)$, in combination with a continuous methanol production, could be an additional pathway for the nighttime methanol emission from maize plants of stage 1 .

In contrast to the maize plants of stage 1 , nighttime values of methanol emissions, photosynthesis, transpiration and stomatal conductance were very low for the leaves of stage 2 and stage 3 
(Fig. 2e-i). Nighttime methanol emissions accounted for only $3 \%$ of the total diurnal emissions, which is about 10 times less than for the fully enclosed plants of stage 1 . Furthermore, the methanol emission peaks following light/dark transitions, which were so prominent for the plants of stage 1 , no longer appeared in the diurnal methanol emission pattern of the leaves of stage 2 and stage 3 . This is in line with the total absence of guttation on leaves of stages 2 and 3.

\subsection{Leaf age affects the magnitude of methanol emission}

Beside large differences in the methanol emission pattern, methanol emission magnitudes were also observed to vary strongly between maize plants of stage 1 and maize leaves of stages 2 and 3 (Fig. 2). Whereas, in the course of a day, the emissions ranged between 0.4 and $2.3 \mathrm{nmol} \mathrm{m}^{-2} \mathrm{~s}^{-1}$ (between 3 and $16 \mu \mathrm{g} \mathrm{g}_{\mathrm{DW}}^{-1} \mathrm{~h}^{-1}$ ) for the plants of stage 1 , variations between 0 and $0.1 \mathrm{nmol} \mathrm{m}^{-2} \mathrm{~s}^{-1}$ $\left(0-0.4 \mu \mathrm{g} \mathrm{g}_{\mathrm{DW}}^{-1} \mathrm{~h}^{-1}\right)$ were measured for the leaves of stages 2 and 3 .

Although the magnitude of methanol emissions from leaves of stages 2 and 3 was found to be very similar (Fig. $2 \mathrm{f}$ and i), it should be noted that 3 of the 5 individual leaves of stage 3 that were enclosed for analysis showed some discoloration at their edges (yellow/brown). The discoloration was an indication of the onset of the senescence process, which is rather common for leaves of this age. The health condition of those leaves was also reflected in reduced photosynthesis and leaf transpiration. The methanol emission patterns of the less healthy leaves of stage 3, however, did not vary significantly from those of the healthy leaves of stage 3 , neither in shape nor in magnitude. This suggests that possible reductions in the methanol emissions by the enclosed leaf due to a reduction of the healthy part of the leaf might be compensated for by an enhanced production of methanol in the senescent part of the leaf.

When expressed per leaf area, total/daytime (i.e. PPFD >0)/ maximum methanol emissions are lower for the leaves of stages 2 and 3 than for the plants of stage 1 by a factor of 17/12/13 (Fig. 2c, $f$ and $2 \mathrm{i}$ ). The difference between total and daytime emissions is explained by the large nighttime contribution to the emissions from the plants of stage 1 . As the specific leaf area (SLA = leaf area per unit of dry mass) of leaves of stages 2 and $3\left(0.034 \mathrm{~m}^{2} \mathrm{~g}_{\mathrm{DW}}^{-1}\right)$ differs from the one of leaves of stage $1\left(0.062 \mathrm{~m}^{2} \mathrm{~g}-1 \mathrm{~W}\right)$, these methanol emission ratios will increase by a factor of 1.8 when expressing the methanol emission rates per leaf dry weight.

A reduction in methanol emission rates along with the maturity of the leaf is a well-known phenomenon which is related to the decrease in leaf growth with time and which has been reported by several other researchers (MacDonald and Fall, 1993; NemecekMarshall et al., 1995; Galbally and Kirstine, 2002; Hüve et al., 2007; Aalto et al., 2014). Reduction levels found in our study are in line with previous measurements on other crop, broadleaf and needleleaf species, which have been recently compiled by Wells et al. (2012).

However, even though the observed reduction in methanol emissions with leaf age is in line with the existing literature, the methanol emission rate data for the leaves of stages 2 and 3 that were observed in the present study differ quite strongly from the ones in other maize studies (Table 2).

In the laboratory study of MacDonald and Fall (1993) and the field study of Das et al. (2003) methanol emission rates as high as 46 and $35 \mu \mathrm{g} \mathrm{g}-1 \mathrm{DW}^{-1}$ have been observed, respectively. In contrast, a more recent field study by Graus et al. (2013) resulted in emission rates of $3.74 \mu \mathrm{g} \mathrm{g}-1 \mathrm{DW}^{-1}$. In our study the maximum average daytime emission rate for the leaves of stages 2 and 3 was only $0.4 \mu \mathrm{g} \mathrm{g}_{\mathrm{DW}}^{-1} \mathrm{~h}^{-1}$. Such disagreement amongst the data can have several reasons, such as differences in maize varieties, plant physiological conditions and the actual conditions under which plants are grown (e.g. light, temperature, soil type, soil fertility and soil moisture content). Although still smaller by a factor 2 , our results for stage 2 and 3 maize leaves at maximum PPFD agree better with the recent eddy covariance methanol flux measurements obtained over a maize field (same variety as in this study) in Belgium (Bachy et al., 2016) at similar light and temperature and plant developmental conditions. Comparison of leaf scale and ecosystem scale measurements, however, is not straightforward and the difference in methanol flux values with Bachy et al. (2016) could have several reasons such as the simultaneous contribution from growing and fully mature leaves, emissions from the soil and other parts of the plant (flowers, fruit), and the variation of light and temperature in the canopy. Because of these important differences amongst studies, more experiments are definitely required in order to

Table 2

Methanol fluxes from this work and previous studies on maize, and corresponding measurement scale, plant age, and environmental conditions.

\begin{tabular}{|c|c|c|c|c|c|c|c|}
\hline & \multicolumn{3}{|l|}{ This study } & \multirow[t]{2}{*}{ MacDonald and Fall (1993) } & \multirow[t]{2}{*}{ Graus et al. (2013) } & \multirow[t]{2}{*}{ Das et al. (2003) } & \multirow{2}{*}{$\begin{array}{l}\text { Bachy et al. (2016) } \\
\text { d }\end{array}$} \\
\hline & stage 1 & stage 2 & stage 3 & & & & \\
\hline $\begin{array}{l}\text { Measurement scale } \\
\text { Plant age (days) }\end{array}$ & $\begin{array}{l}\text { plant/leaf } \\
4-14\end{array}$ & $\begin{array}{l}\text { leaf } \\
30-40\end{array}$ & $\begin{array}{l}\text { leaf } \\
60-70\end{array}$ & $\begin{array}{l}\text { leaf } \\
*\end{array}$ & leaf & ecosystem & $\begin{array}{l}\text { ecosystem } \\
73-96\end{array}$ \\
\hline $\begin{array}{l}\text { Analytical instrument } \\
\text { Measurement } \\
\text { technique }\end{array}$ & $\begin{array}{l}\text { PTR-MS } \\
\text { enclosure } \mathrm{m} \\
\text { temperature } \\
\text { environmen }\end{array}$ & $\begin{array}{l}\text { PTR-MS } \\
\text { neasurements i } \\
\text { e and light con } \\
\text { ntal chamber }\end{array}$ & $\begin{array}{l}\text { PTR-MS } \\
\text { in a } \\
\text { ntrolled }\end{array}$ & $\begin{array}{l}\text { GC-MS } \\
\text { in situ enclosure } \\
\text { measurements }\end{array}$ & $\begin{array}{l}\text { PTR-MS } \\
\text { in situ enclosure } \\
\text { measurements }\end{array}$ & $\begin{array}{l}\text { GC-FID } \\
\text { flux-gradient } \\
\text { technique }\end{array}$ & $\begin{array}{l}\text { PTR-MS } \\
\text { DEC-MS }\end{array}$ \\
\hline $\begin{array}{l}\text { PPFD } \\
{\left[\mu \mathrm{mol} \mathrm{m}^{-2} \mathrm{~s}^{-1}\right]}\end{array}$ & $0-600$ & $0-600$ & $0-600$ & 350 & 1000 & $300-950$ & $500-700$ \\
\hline $\mathrm{T}\left({ }^{\circ} \mathrm{C}\right)$ & $23-27$ & $23-27$ & $23-27$ & 30 & 30 & $24-28$ & $23-27$ \\
\hline $\begin{array}{l}\text { Average } \mathrm{E}_{\mathrm{CH} 3 \mathrm{OH}} \\
{\left[\mu \mathrm{g} \mathrm{g}_{\mathrm{DW}}^{-1} \mathrm{~h}^{-1}\right]}\end{array}$ & $\begin{array}{l}5.7 \pm 0.7^{\mathrm{a}} \\
(7.1 \pm 0.8)\end{array}$ & $\begin{array}{l}0.17 \pm 0.03^{\mathrm{a}} \\
(0.35 \pm 0.07)\end{array}$ & $\begin{array}{l}0.20 \pm 0.04^{\mathrm{a}} \\
(0.37 \pm 0.06)\end{array}$ & $45.7 \pm 2.7$ & 3.74 & $34.50 \pm 14.56^{c}$ & $0.75 \pm 0.12$ \\
\hline
\end{tabular}

\footnotetext{
* Youngest fully developed leaves, plant age not reported.

a Daily average emission rate.

b Average emission rate at maximum PPFD $\left(600 \mu \mathrm{mol} \mathrm{m}^{-2} \mathrm{~s}^{-1}\right)$.

c Taking into account a biomass dry weight of $100 \mathrm{~g}$ per $\mathrm{m}^{2}$ of soil surface area (Das et al., 2003).

d This study was carried out over an entire growth season, but only data from 73 to 96 days old maize plants (developmental stage R1 in Bachy et al., 2016) and within the

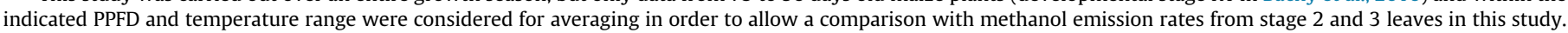

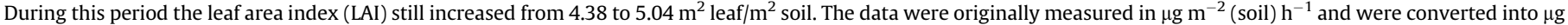
$\mathrm{g} \mathrm{DW}^{-1}$ (leaf) $\mathrm{h}^{-1}$ by dividing the emissions by the LAI (measured on site) and the specific leaf weight (estimated at $29 \mathrm{~g}$ per $\mathrm{m}^{2}$ leaf) (A. Bachy, personal communication).

e DEC-MS: Disjunct Eddy Covariance by Mass Scanning.
} 
constrain methanol emissions from this crop species.

\section{Conclusions}

This study revealed strong differences in the response of methanol emissions to varying PPFD between maize plants of stage 1 (young) and maize leaves of stage 2 (almost fully grown) and stage 3 (fully grown). Methanol emissions for the plants of stage 1 showed a continuous rise towards a maximum in the course of the day which was followed by a decline towards the end of the photoperiod. This indicates that the production was modulated by a response to some other factor than light and temperature, such as a diurnal variation in leaf growth rate or PME activity. On the other hand, methanol emissions from leaves of stages 2 and 3 closely followed changes in PPFD, transpiration and stomatal conductance. They were also reproduced fairly well by the dynamic BVOC emission model of Niinemets and Reichstein when a production function dependent on both PPFD and temperature was used.

In contrast to leaves of stages 2 and 3, plants of stage 1 were characterized by non-negligible nighttime emissions of methanol and by the occurrence of large peaks following light/dark transitions. Simultaneous observations of guttation droplets on maize leaves of stage 1 suggested guttation as a hypothetical source of this emission peak. This hypothesis was strengthened by a quantification of the methanol content in the guttation fluid. Similar concentrations of methanol were also found in the guttation fluid of young winter wheat (Triticum aestivum L.) plants. Future studies on other plant species may be useful to better evaluate the significance of this additional methanol emission pathway.

The present study also confirmed that methanol emission from plants of stage 1 is larger than the one from leaves of stages 2 and 3 by an order of magnitude. This supports the current hypothesis that methanol emission from plants of stage 1 is strongly related to leaf growth. Emission rates in our study were rather low compared to other studies, but in fair agreement with a recent whole growing season ecosystem scale study, carried out above a maize field in Belgium and using the same maize variety as in the present study. A comparison of the flux measurements from leaves of stage 2 and stage 3 also indicated that the onset of senescence in highly mature leaves of stage 3 is an additional source of methanol.

In conclusion, this study shows that methanol emissions from maize plants are complex and differ strongly between developmental stages. It turns out little is yet understood of the emissions from plants of stage 1 in particular. Additional growth chamber and field studies, covering a wide range of environmental conditions and possibly also involving other crop species at different developmental stages, will be required in order to develop accurate methanol emission algorithms for agricultural crops.

\section{Acknowledgements}

We gratefully acknowledge the financial support provided by FNRS (Fonds National de la Recherche Scientifique) for funding the CROSTVOC research project (grant number T.0086.13), in the framework of which this study was carried out. We are also very grateful for the indispensable technical support provided by the employees of the Belgian Institute for Space Aeronomy and the University of Liège, Gembloux Agro-Bio Tech.

\section{Appendix A. Supplementary data}

Supplementary data related to this article can be found at http:// dx.doi.org/10.1016/j.atmosenv.2016.12.041.

\section{References}

Aalto, J., Kolari, P., Hari, P., Kerminen, V.M., Schiestl-Aalto, P., Aaltonen, H., Levula, J., Siivola, E., Kulmala, M., Bäck, J., 2014. New foliage growth is a significant, unaccounted source for volatiles in boreal evergreen forests. Biogeosciences 11, 1331-1344. http://dx.doi.org/10.5194/bg-11-1331-2014.

Bachy, A., Aubinet, M., Schoon, N., Amelynck, C., Bodson, B., Moureaux, C. Heinesch, B., 2016. Are BVOC exchanges in agricultural ecosystems overestimated? insights from fluxes measured in a maize field over a whole growing season. Atmos. Chem. Phys. 16, 5343-5356. http://dx.doi.org/10.5194/acp-165434-2016.

Bracho-Nunez, A., Welter, S., Staudt, M., Kesselmeier, J., 2011. Plant-specific volatile organic compound emission rates from young and mature leaves of Mediterranean vegetation. J. Geophys. Res. 116, D16304. http://dx.doi.org/10.1029/ 2010JD015521.

Brunner, A., Ammann, C., Neftel, A., Spirig, C., 2007. Methanol exchange between grassland and the atmosphere. Biogeosciences 4, 395-410. http://dx.doi.org/ 10.5194/bg-4-395-2007.

Caird, M.A., Richards, J.M., Donovan, L.A., 2007. Nighttime stomatal conductance and transpiration in C3 and C4 plants. Plant Physiol. 143, 4-10.

Choi, W., Faloona, I.C., Bouvier-Brown, N.C., McKay, M., Goldstein, A.H., Mao, J., Brune, W.H., LaFranchi, B.W., Cohen, R.C., Wolfe, G.H., Thornton, J.A Sonnenfroh, D.M., Millet, D.B., 2010. Observations of elevated formaldehyde over a forest canopy suggest missing sources from rapid oxidation of arboreal hydrocarbons. Atmos. Chem. Phys. 10, 8761-8781. http://dx.doi.org/10.5194/ acp-10-8761-2010.

Custer, T., Schade, G., 2007. Methanol and acetaldehyde fluxes over ryegrass. Tellus. B. 59, 673-684. http://dx.doi.org/10.1111/j.1600-0889.2007.00294.x.

Das, M., Kang, D., Aneja, V.P., Lonneman, W., Cook, D.R., Wesely, M.L., 2003. Measurements of hydrocarbon air-surface exchange rates over maize. Atmos. Environ. 37 (16), 2269-2277.

Duncan, B.N., Logan, J.A., Bey, I., Megretskaia, I.A., Yantosca, R.M., Novelli, P.C., Jones, N.B., Rinsland, C.P., 2007. Global budget of CO, 1988-1997: source estimates and validation with a global model. J. Geophys. Res. 112 (D22), D22301, http://dx.doi.org/10.1029/2007JD008459.

Ellis, A.M., Mayhew, C.A., 2014. Proton Transfer Reaction Mass Spectrometry Principles and Applications. John Wiley and Sons, United Kingdom.

Fall, R., Benson, A.A., 1996. Leaf methanol - the simplest natural product from plants. Trends Plant Sci. 1, 296-301.

FAO (Food and Agriculture Organization of the United Nations), FAOSTAT database. FAO, Rome, Italy. Available at: http://faostat3.fao.org. Accessed on 24 September 2015.

Folkers, A., Hüve, K., Ammann, C., Dindorf, T., Kesselmeier, J., Kleist, E., Kuhn, U. Uerlings, R., Wildt, J., 2008. Methanol emissions from deciduous tree species: dependence on temperature and light intensity. Plant Biol. 10, 65-75. http:// dx.doi.org/10.1111/j.1438-8677.2007.00012.x.

Galbally, I., Kirstine, W., 2002. The production of methanol by flowering plants and the global cycle of methanol. J. Atmos. Chem. 43, 195-229.

Graus, M., Eller, A., Fall, R., Yuan, B., Qian, Y., Westra, P., de Gouw, J., Warneke, C. 2013. Biosphere-atmosphere exchange of volatile organic compounds over C4 biofuel crops. Atmos. Environ. 66, 161-168.

Harley, P., 2013. The roles of stomatal conductance and compound volatility in controlling the emission of volatile organic compounds from leaves. In: Niinemets, Ü., Monson, R.K. (Eds.), Biology, Controls and Models of Tree Volatile Organic Compound Emissions. Springer, Berlin, pp. 181-208.

Harley, P., Greenberg, J., Niinemets, Ü., Guenther, A., 2007. Environmental controls over methanol emission from leaves. Biogeosciences 4, 1083-1099. http:/ dx.doi.org/10.5194/bg-4-1083-2007.

Harriman, R.W., Tieman, D.M., Handa, A.K., 1991. Molecular cloning of tomato pectin methylesterase gene and its expression in rutgers, ripening inhibitor, nonripening, and never ripe tomato fruits. Plant Physiol. 97, 80-87.

Heikes, B.G., Chang, W., Pilson, M.E.Q., Swift, E., Singh, H.B., Guenther, A., Jacob, D.J., Field, B.D., Fall, R., Riemer, D., Brand, L., 2002. Atmospheric methanol budget and ocean implication. Glob. Biogeochem. Cy. 16, 1133,. http://dx.doi.org/ 10.1029/2002GB001895.

Hu, L., Millet, D.B., Mohr, M.J., Wells, K.C., Griffis, T.J., Helmig, D., 2011. Sources and seasonality of atmospheric methanol based on tall tower measurements in the US upper midwest. Atmos. Chem. Phys. 11, 11145-11156. http://dx.doi.org/ 10.5194/acp-11-11145-2011.

Hüve, K., Christ, M.M., Kleist, E., Uerlings, R., Niinemets, U., Walter, A., Wildt, J., 2007. Simultaneous growth and emission measurements demonstrate an interactive control of methanol release by leaf expansion and stomata. J. Exp. Bot. 58, 1783-1793. http://dx.doi.org/10.1093/jxb/erm038.

Jacob, D.J., Field, B.D., Li, Q., Blake, D.R., de Gouw, J., Warneke, C., Hansel, A Wisthaler, A., Singh, H.B., Guenther, A., 2005. Global budget of methanol: constraints from atmospheric observations. J. Geophys. Res. 110, D08303. http:// dx.doi.org/10.1029/2004JD005172.

Joachimsmeier, I., Pistorius, J., Heimbach, U., Schenke, D., Kirchner, W., Zwerger, P., 2011. Frequency and insstensity of guttation events in different crops in Germany, Julius-Kühn-Archiv, 11th International Symposium of the ICP-BR Bee Protection Group, Wageningen (The Netherlands), November 2-4. http:// dx.doi.org/10.5073/jka.2012.437.020.

Karl, T., Guenther, A., Spirig, C., Hansel, A., Fall, R., 2003. Seasonal variation of biogenic VOC emissions above a mixed hardwood forest in northern Michigan. 
Geophys. Res. Lett. 30, 2186. http://dx.doi.org/10.1029/2003GL018432.

Karl, T., Potosnak, M., Guenther, A., Clark, D., Walker, J., Herrick, J.D., Geron, C., 2004 Exchange processes of volatile organic compounds above a tropical rain forest: implications for modeling tropospheric chemistry above dense vegetation. J. Geophys. Res. 109, D18306. http://dx.doi.org/10.1029/2004JD004738.

Karl, T., Harley, P., Guenther, A., Rasmussen, R., Baker, B., Jardine, K., Nemitz, E., 2005. The bi-directional exchange of oxygenated VOCs between a loblolly pine (Pinus taeda) plantation and the atmosphere. Atmos. Chem. Phys. 5, 3015-3031. http://dx.doi.org/10.5194/acp-5-3015-2005.

Laffineur, Q., Aubinet, M., Schoon, N., Amelynck, C., Müller, J.-F., Dewulf, J., Van Langenhove, H., Steppe, K., Heinesch, B., 2012. Abiotic and biotic control of methanol exchanges in a temperate mixed forest. Atm. Chem. Phys. 12, 577-590. http://dx.doi.org/10.5194/acp-12-577-2012.

Lindinger, W., Hansel, A., Jordan, A., 1998. On-line monitoring of volatile organic compounds at pptv levels by means of proton-transfer reaction mass spectrometry (PTR-MS) - medical applications, food control and environmental research. Int. J. Mass Spectrom. 173 (3), 191-241.

MacDonald, R.C., Fall, R., 1993. Detection of substantial emissions of methanol from plants to the atmosphere. Atmos. Environ. Part A General Top. 27, 1709-1713.

Millet, D.B., Jacob, D.J., Turquety, S., Hudman, R.C., Wu, S., Fried, A., Walega, J. Heikes, B.G., Blake, D.R., Singh, H.B., Anderson, B.E., Clarke, A.D., 2006. Formaldehyde distribution over North America: implications for satellite retrievals of formaldehyde columns and isoprene emission. J. Geophys. Res. 111, D24S02. http://dx.doi.org/10.1029/2005JD006853.

Millet, D.B., Jacob, D.J., Custer, T.G., de Gouw, J.A., Goldstein, A.H., Karl, T., Singh, H.B. Sive, B.C., Talbot, R.W., Warneke, C., Williams, J., 2008. New constraints on terrestrial and oceanic sources of atmospheric methanol. Atmos. Chem. Phys. 8 (23), 6887-6905. http://dx.doi.org/10.5194/acp-8-6887-2008.

Mokhtarpour, H., Teh, C.B.S., Saleh, G., Selmat, A.B., Asadi, M.E., Kamkar, B., 2010 Non destructive estimation of maize leaf area, fresh weight, and dry weight using leaf length and leaf width. Commun. Biometry Crop Sci. 5, 19-26.

Nemecek-Marshall, M., MacDonald, R.C., Franzen, J.J., Wojciechowski, C.L., Fall, R. 1995. Enzymatic detection of gas-phase methanol and relation of methano fluxes to stomatal conductance and leaf development. Plant Physiol. 108, 1359-1368.

Niinemets, Ü., Fares, S., Harley, P., Jardine, K.J., 2014. Bidirectional exchange of biogenic volatiles with vegetation: emission sources, reactions, breakdown and deposition. Plant Cell Environ. 37 (8), 1790-1809. http://dx.doi.org/10.1111/ pce.12322.

Oikawa, P.Y., Li, L., Timko, M.P., Mak, J.E., Lerdau, M.T., 2011. Short term changes in methanol emission and pectin methylesterase activity are not directly affected by light in Lycopersicon esculentum. Biogeosciences 8, 1023-1030. http:// dx.doi.org/10.5194/bg-8-1023-2011.

Pearcy, R.W., Schultze, E.-D., Zimmermann, R., 1989. Chapter 8: measurement of transpiration and leaf conductance. In: Pearcy, R.W., Ehleringer, J., Mooney, H.A. Rundel, P.W. (Eds.), Plant Physiological Ecology: Field Methods and Instrumentation. Chapman and Hall Ltd, London, pp. 137-160.

Poiré, R., Wiese-Klinkenberg, A., Parent, B., Mielewczik, M., Schurr, U., Tardieu, F. Walter, A., 2010. Diel time-courses of leaf growth in monocot and dicot species: endogenous rhythms and temperature effects. J. Exp. Bot. 61, 1751-1759. http:/ dx.doi.org/10.1093/jxb/erq049.

Niinemets, Ü., Reichstein, M., 2003a. Controls on the emission of plant volatiles through stomata: differential sensitivity of emission rates to stomatal closure explained. J. Geophys. Res. 108, 4208. http://dx.doi.org/10.1029/2002JD002620.

Niinemets, Ü., Reichstein, M. 2003b. Controls on the emission of plant volatiles through stomata: a sensitivity analysis. J. Geophys. Res. 108, 4211. http:// dx.doi.org/10.1029/2002JD002626.

Riemer, D., Pos, W., Milne, P., Farmer, C., Zika, R., Apel, E., Olszyna, K., Kliendienst, T., Lonneman, W., Bertman, S., Shepson, P., Starn, T., 1998. Observations of nonmethane hydrocarbons and oxygenated volatile organic compounds at a rural site in the southeastern United States. J. Geophys. Res. 103, 28111-28128.

Schade, G.W., Goldstein, A.H., 2001. Fluxes of oxygenated volatile organic compounds from a ponderosa pine plantation. J. Geophys. Res. 106, 3111-3123.

Schade, G.W., Solomon, S.J., Dellwik, E., Pilegaard, K., Ladstätter-Weissenmayer, A., 2011. Methanol and other VOC fluxes from a Danish beech forest during late springtime. Biogeochemistry 106, 337-355.

Seco, R., Penuelas, J., Filella, I., 2007. Short-chain oxygenated VOCs: emission and uptake by plants and atmospheric sources, sinks and concentrations. Atm. Environ. 41 (12), 2477-2499. http://dx.doi.org/10.1016/j.atmosenv.2006.11.029.

Singh, S., 2013. Guttation: path, principles and functions. Austral. J. Bot. 61, 497-515.

Singh, H., Chen, Y., Tabazadeh, A., Fukui, Y., Bey, I., Yantosca, R., Jacob, D., Arnold, F. Wohlfrom, K., Atlas, E., Flocke, F., Blake, D., Blake, N., Heikes, B., Snow, J., Talbot, R., Gregory, G., Sachse, G., Vay, S., Kondo, Y., 2000. Distribution and fate of selected oxygenated organic species in the troposphere and lower stratosphere over the Atlantic. J. Geophys. Res. 105, 3795-3805.

Stavrakou, T., Guenther, A., Razavi, A., Clarisse, L., Clerbaux, C., Coheur, P.-F., Hurtmans, D., Karagulian, F., De Mazière, M., Vigouroux, C., Amelynck, C., Schoon, N., Laffineur, Q., Heinesch, B., Aubinet, M., Rinsland, C., Müller, J.-F., 2011. First space-based derivation of the global atmospheric methanol emission fluxes. Atmos. Chem. Phys. 11, 4873-4898. http://dx.doi.org/10.5194/acp-114873-2011.

Taiz, L., Zeiger, E., 2010. Plant Physiology, 502 and 508-509, 2010, fifth ed. Sinauer Associates Inc., Sunderland.

Takeda, F., Wisniewski, M.E., Glenn, D.M., 1991. Occlusion of water pores prevents guttation in older strawberry leaves. J. Amer. Soc. Hort. Sci. 116 (6), 1122-1125.

Tie, X., Guenther, A., Holland, E., 2003. Biogenic methanol and its impacts on tropospheric oxidants. Geophys. Res. Lett. 30, 1881,. http://dx.doi.org/10.1029/ 2003 GL017167.

von Kuhlmann, R., Lawrence, M.G., Crutzen, P.., Rasch, P.J., 2003. A model for studies of tropospheric ozone and nonmethane hydrocarbons: model evaluation of ozone-related species. J. Geophys. Res. 108, 4729,. http://dx.doi.org/ 10.1029/2002JD003348.

Wells, K.C., Millet, D.B., Hu, L., Cady-Pereira, K.E., Xiao, Y., Shephard, M.W. Clerbaux, C.L., Clarisse, L., Coheur, P.-F., Apel, E.C., de Gouw, J., Warneke, C., Singh, H.B., Goldstein, A.H., Sive, B.C., 2012. Tropospheric methanol observations from space: retrieval evaluation and constraints on the seasonality of biogenic emissions. Atmos. Chem. Phys. 12, 3941-3982. http://dx.doi.org/ 10.5194/acp-12-5897-2012.

Wohlfahrt, G., Amelynck, C., Ammann, C., Arneth, A., Bamberger, I., Goldstein, A.H., Gu, L., Guenther, A., Hansel, A., Heinesch, B., Holst, T. Hörtnagl, L., Karl, T., Laffineur, Q., Neftel, A., McKinney, K., Munger, J.W., Pallardy, S.G., Schade, G.W., Seco, R., Schoon, N., 2015. An ecosystem-scale perspective of the net land methanol flux: synthesis of micrometeorological flux measurements. Atmos. Chem. Phys. 15, 7413-7427. http://dx.doi.org/10.5194/acp-15-7413-2015. 